\title{
Contribution of Electrolysis within an Integrated System for a Poultry Slaughterhouse Wastewater Treatment
}

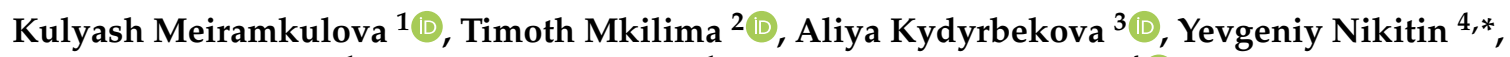 \\ Amanbek Zandybay ${ }^{1}$, Mansur Khussainov ${ }^{1}$ and Tatyana Uryumtseva ${ }^{4}$ (D) \\ 1 Department of Environmental Engineering and Management, L.N. Gumilyov Eurasian National University, \\ Nur-Sultan 010000, Kazakhstan; kuleke@gmail.com (K.M.); amanbek_z@mail.ru (A.Z.); \\ kh-mansur@mail.ru (M.K.) \\ 2 Department of Civil Engineering, Faculty of Architecture and Construction, L.N. Gumilyov Eurasian \\ National University, Nur-Sultan 010000, Kazakhstan; tmkilima@gmail.com \\ 3 Department of Management, L.N. Gumilyov Eurasian National University, Nur-Sultan 010000, Kazakhstan; \\ aliyafromkz@gmail.com \\ 4 Faculty of Engineering and Technology, llP "Innovative University of Eurasia”, Pavlodar 140000, Kazakhstan; \\ vbh2@mail.ru \\ * Correspondence: yevgeniynikitin1964@gmail.com
}

check for updates

Citation: Meiramkulova, K.; Mkilima, T.; Kydyrbekova, A.; Nikitin, Y.; Zandybay, A.; Khussainov, M.; Uryumtseva, T. Contribution of Electrolysis within an Integrated System for a Poultry Slaughterhouse Wastewater Treatment. Sustainability 2021, 13, 12430. https://doi.org/ $10.3390 /$ su132212430

Academic Editor: Andreas N. Angelakis

Received: 5 October 2021

Accepted: 9 November 2021

Published: 10 November 2021

Publisher's Note: MDPI stays neutral with regard to jurisdictional claims in published maps and institutional affiliations.

Copyright: (c) 2021 by the authors. Licensee MDPI, Basel, Switzerland. This article is an open access article distributed under the terms and conditions of the Creative Commons Attribution (CC BY) license (https:/ / creativecommons.org/licenses/by/ $4.0 /)$.

\begin{abstract}
Treatment of poultry slaughterhouse wastewater before disposal or reuse is an essential part of human health and environmental protection in general. This study aimed to investigate the influence of the pre-treatment system based on electrolysis technology within an integrated lab-scale treatment plant in the removal of contaminants from poultry slaughterhouse wastewater. Several treatment units (averaging tank, feather catcher, fat catcher, and coarse mechanical filter) were connected in series before the electrolysis chamber. While in general, the entire integrated system also included some other units such as ultra-filtration, reverse osmosis, and the ultraviolet lamp connected in series. From the analysis results, it was observed that the pre-treatment phase with electrolysis had a significant influence on the general performance of the treatment plant. The pre-treatment contributed to about $33.5 \%$ to $100 \%$ in the general contaminants' removal efficiency. The highest contribution was observed from the total chlorine $(100 \%)$, nitrate $(98.2 \%)$, as well as BOD $(95.3 \%)$. The lowest contribution was observed from the nitrite removal, with $33.5 \%$. This study revealed further that the integration of electrolysis technology in a wastewater treatment system has a significant potential for developing an effective wastewater treatment plant.
\end{abstract}

Keywords: electrolysis; treatment efficiency; poultry slaughterhouse; wastewater treatment; water quality

\section{Introduction}

The increase in population has also been increasing the demand for industrial products including poultry products. When water is subjected to a production line, there is a high possibility of collecting several pollutants with making it unsuitable for direct use for portable needs. Generally, wastewater from a poultry slaughterhouse is mainly a mixture of the processing water from both the slaughtering line and the cleaning of the poultry products. The wastewater generated from the poultry slaughterhouse contains a large variation in the concentration of organic matter such as proteins, carbohydrates, fats and oils, and trace amounts [1].

In this matter, discharging untreated poultry slaughterhouse wastewater into a municipal or any other sewage system before purification may create severe problems [2,3]. Therefore, the treatment of slaughterhouse wastewater is of high importance to prevent the high organic loading to municipal wastewater treatment plants. Nowadays, there are many technologies used for the treatment of slaughterhouse wastewaters including fine screening 
to remove large and small particles [4], settling of particles through the so-called sedimentation, the combination of coagulation and flocculation, and other biological treatment systems such as trickling filters and activated sludge [5]. Apart from the environment in general, untreated slaughterhouse wastewater discharged into water bodies may also have diverse effects on the receiving water body, endangering the aquatic life, and facilitating eutrophication as a few examples [6].

The poultry slaughterhouse wastewater can be purified using physical, chemical, and biological treatment approaches. But each treatment approach is characterized by strengths and weaknesses. Starting with the physical treatment systems such as membrane filtration [7]; these systems are characterized by high efficiency in terms of pollutant removal, but they are energy-intensive as they demand high pressure to operate [8], fouling issues [9] as well as generating huge volumes of sludge that has to be separately handled. In that matter, the processes are relatively expensive, accompanied by feasibility issues for large-scale operations. The biological technologies are well known in terms of adaptability to changing wastewater compositions [10]. However, being slow processes, requiring large physical areas, and generating large amounts of sludge are among the challenges associated with these systems. Therefore, chemical treatment technologies such as electrochemical (EC) processes have emerged as alternative treatment systems, offering a number of advantages such as robustness, small space requirements, relatively easy operation, as well as being flexible when subjected to fluctuating wastewater composition [11]. Something very important to be noted here is that different electrode materials may, however, perform differently in wastewater treatment even for wastewater with similar characteristics, which makes it challenging to predict the behavior of electrochemical systems [12,13].

Electrolysis is an electrochemical wastewater treatment technology that is currently experiencing both increased popularity and significant technical improvement [14]. It is a complex process involving many chemical and physical phenomena that use consumable electrodes to supply ions into the wastewater.

In general, a reactor of an electrochemical treatment plant consists of an electrolytic cell with an anode on one side and a cathode on the other side [15]. When the system is connected to a power source, the oxidation process occurs in the anode making it electrochemically corroded, while passivation occurs in the cathode. The main processes in the electrochemical system can be represented using chemical equations [16] (Equations (1) and (2)).

At electrode surfaces

$$
\begin{gathered}
\text { Anode: } \mathrm{M} \rightarrow \mathrm{M}^{3+}{ }_{(\mathrm{aq})}+3 \mathrm{e}^{-} \\
\text {Cathode }: 3 \mathrm{H}_{2} \mathrm{O}+3 \mathrm{e}^{-} \rightarrow \frac{3}{2} \mathrm{H}_{2}+3 \mathrm{OH}^{-}
\end{gathered}
$$

where:

$\mathrm{M}$ is an electrode such as graphite ( $\mathrm{Gr})$, iron (Fe), or aluminium (Al)

Coagulation in the aqueous phase.

$\mathrm{M}^{3+}{ }_{(\mathrm{aq})}$ and $\mathrm{OH}^{-}$ions from Equations (1) and (2) above react to form hydroxo monomeric and polymeric species, which will then change to $\mathrm{M}(\mathrm{OH}) 3$ according to $\mathrm{pH}$ range [17].

After forming the amorphous $\mathrm{M}(\mathrm{OH}) 3$ also known as sweep flocs, can be useful for the removal of colloidal particles through rapid adsorption of soluble organic compounds. While through polymerization, the formed flocs can be removed by sedimentation and floatation [18].

However, depending on the operating scale, to achieve a high-quality effluent based on electrochemical methods alone can be a challenge. Therefore, integrating the electrochemical methods with other treatment units such as membrane filtration and ultraviolet disinfection is always preferable [19]. However, the information on how an electrochemical method can contribute to the general performance of an integrated wastewater treatment system is still scarce. 
In this study, the potential influence of electrolysis in the performance of an integrated or combined lab-scale wastewater treatment system was investigated. The samples collected from the Izhevsk Production Cooperative (PC) poultry were treated using the labscale treatment plant. The main parameters investigated in this study were $\mathrm{pH}$, turbidity, color, total suspended solids (TSS), free chlorine, total chlorine, nitrite, nitrogen, nitrate, nitrogen, phosphates, ammonium, iron total, aluminium, COD as well as BOD.

\section{Materials and Methods}

\subsection{Case Study Description}

The wastewater samples used in this study were collected from the Izhevsk PC poultry slaughterhouse located in Izhevsk village, Arshalinsky district, in Akmola region of the Republic of Kazakhstan, approximately $70 \mathrm{~km}$ distance from the capital city Nur-Sultan $\left(51^{\circ} 10^{\prime}\right.$ North latitude and $71^{\circ} 26^{\prime}$ East longitude). The current production capacity of the Izevski poultry farm is 280 million eggs per year. The poultry farm has also imported new cages with a capacity of accommodating 1 million laying hens. The meat production capacity of the poultry farm is 3000 tons per year. The poultry products are daily delivered to the capital city, Nur-Sultan, as well as other cities of Kazakhstan and Russia.

The production processes of the slaughterhouse generate wastewater from the live bird processing to the cooling section; with defeathering, evisceration, and cooling processes being the main sources of wastewater generation in the slaughterhouse (Figure 1). The slaughterhouse processes of the poultry farm generate approximately $2.2 \mathrm{~m}^{3}$ of wastewater per hour. The case study was selected because is one of the largest poultry farms in Central Asia. Currently, the wastewater generated at the poultry farm is mainly discharged to the biological treatment system of the Izevski village.

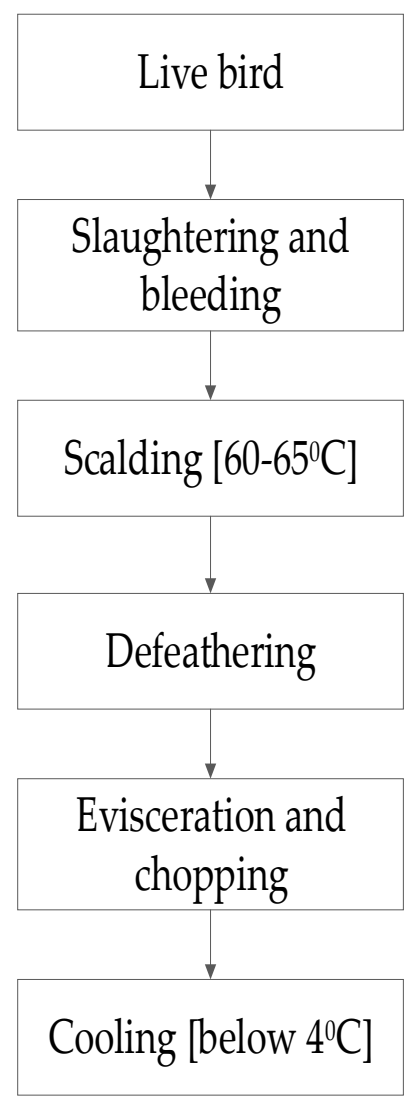

Figure 1. Production flowchart. 
The climatic condition around the case study is characterized by an extreme continental climate, with long cold winters and some hot summers. In some years, winter temperatures reach $-52{ }^{\circ} \mathrm{C}$. In summer, an average temperature of up to $30^{\circ} \mathrm{C}$ can be observed. Generally, precipitation around the case study amounts to $320 \mathrm{~mm}$ per year, with a relative minimum in winter, and a relative maximum during the summer.

\subsection{General Wastewater Treatment Setup (in Laboratory)}

The treatment plant is composed of a mini reservoir with a macro-filter installed to separate feathers and organic components from the wastewater. The electrochemical process takes place within a reactor connected in series to the min reservoir. The effluent purified by the EC unit was subjected to a sedimentary cylinder where the particles in suspension settle down and come to rest against the barrier. A pump (pressure capacity of 5.5 bar) was then utilized to transfer water from the sedimentary cylinder to the ultrafilter with a pore size of $0.02 \mu \mathrm{m}$, enough to trap sediments not smaller than its pore size, including most bacteria and viruses.

Moreover, the ultra-filtered water was subjected to another small reservoir where a small pump conveys the water to a UV sterilizer to kill any remaining microorganism. The water circulates in the UV sterilizer for about $10 \mathrm{~min}$ before the experiment is concluded. After the treatment process, the cleaning of the reservoirs and electrolyte cells was done manually by rinsing with water and disinfectants. The whole treatment process from electrolysis to UV sterilization is summarized in Figure 2.

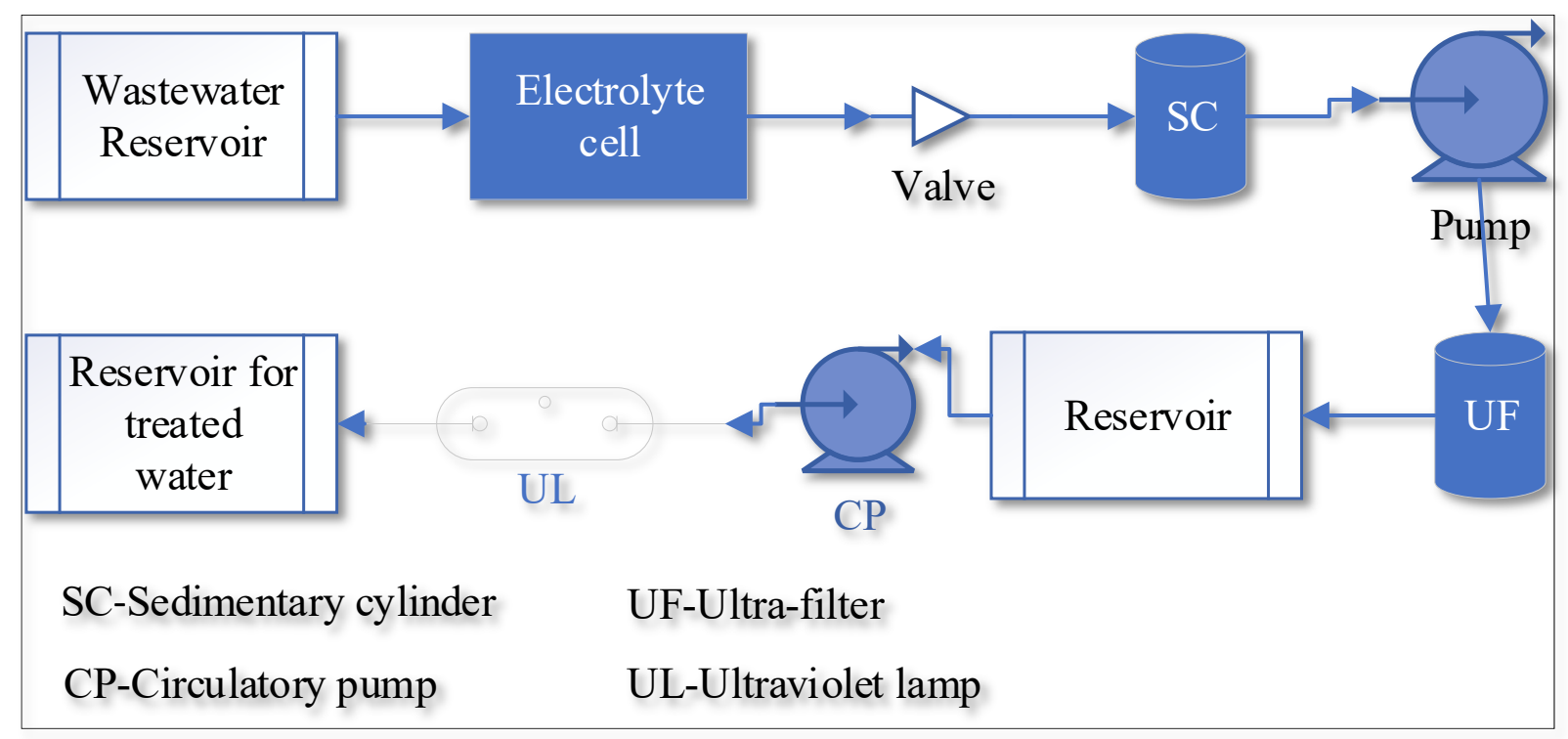

Figure 2. Combined poultry slaughterhouse wastewater treatment system.

\subsection{Electrolysis Setup}

The electrolysis unit is considered to be the main unit within the pre-treatment system. The principle of operation of the electrolysis is based on the fact that coagulation occurs for suspended finely dispersed particles in the installation, due to the electrochemical dissolution of aluminium anodes and the subsequent flotation of suspended particles, with their removal from the total volume of the drain through the outlet pipe of the electrolysis chamber.

Approximately $1.7 \mathrm{~L}$ of wastewater was used in each session of the experiments. In general, the setup of the electrolysis unit included; a reactor or chamber of $15 \mathrm{~cm}$ length $\times 13 \mathrm{~cm}$ width $\times 11 \mathrm{~cm}$ height, made of polypropylene material with electrodes installed in it. Morever, direct current was supplied to both electrodes, which included a power supply (Xinhua Electrical Weld Company, Loudi, China) of 0 to $50 \mathrm{~V}$ for voltage 
and 0 to $10 \mathrm{~A}$ for current density. The materials used for the electrodes were aluminum $10.8 \mathrm{~cm} \times 11.8 \mathrm{~cm} \times 0.2 \mathrm{~cm}$, as well as graphite and titanium with $10.8 \mathrm{~cm} \times 11.8 \mathrm{~cm} \times 0.7 \mathrm{~cm}$ dimensions. A distance of $2 \mathrm{~cm}$ between electrodes was kept constant in all the study sessions and were placed parallel to the reactor. Moreover, the current density varied with the electrode material and wastewater characteristics. Table 1 provides a summary of other specifications in the electrolysis unit.

Table 1. General technical specifications of the electrolysis unit.

\begin{tabular}{ccc}
\hline Parameter & Value & Unit \\
\hline Initial water temperature & $+5-+10$ & ${ }^{\circ} \mathrm{C}$ \\
Potential (voltage) & 24 & $\mathrm{~V}$ \\
Average current density & 5.5 & $\mathrm{~A}$ \\
Average power & 132 & $\mathrm{~W}$ \\
Hydraulic retention time & 20 & $\mathrm{~min}$ \\
\hline
\end{tabular}

\subsection{Analysis of the Samples}

The wastewater samples collected from the Izhevsk PC poultry farm were grouped into two main groups; the samples collected after the electrolysis stage and the samples collected after the complete system. To preserve and maintain the status of the samples, they were stored at $4{ }^{\circ} \mathrm{C}$ before the analysis. Several parameters were tested in the laboratory to characterize the wastewater before and after treatment. The analyses of the samples were accomplished following the recommendations in the APHA, Standard Methods for the Examination of Water and Wastewater (APHA, 2005).

Raw wastewater samples from the Izhevsk PC poultry farm were collected as grab samples using $5 \mathrm{~L}$ plastic bottles, which were thoroughly rinsed with deionized water before use. All samples were preserved at $4{ }^{\circ} \mathrm{C}$ before transporting them to the lab for treatment and analysis. A total of fourteen (14) water quality parameters were investigated in this study, namely; $\mathrm{pH}$, turbidity, color, TSS, free chlorine, total chlorine, nitrite, nitrate, phosphates, ammonium, COD, BOD, aluminium, and total iron.

Moreover, different scientific procedures, kits, and reagents were used to assess the parameters of interest in the water samples. The combination of Spectrophotometer (Hach DR3900, HACH/LANGE, Berlin, Germany), Colorimeter (Hach DR900, Berlin, Germany), with standard reagents as well as the test kits were used to determine the concentrations of COD, free chlorine, total chlorine, nitrites, nitrates, total phosphorous, and ammonium in the water samples. While the U.S. Environmental Protection Agency Great Lakes National Program Office (GLNPO, Washington, DC, USA), Standard Operating Procedure for Turbidity was used for the measurements of turbidity [20]. Moreover, the American Public Health Association (APHA) 4500-Nor was used to determine the concentrations of phosphates [21], while the lab pH-meter Frederick, MD, US was used for pH measurements. The color was determined using the UV-V Spectrophotometer (PE-5400UV) pr-in ECOCHEMICAL, St. Petersburg, Russia [22]. Concentration levels of TSS were determined using the Hach TSS portable hand-held turbidity meter (HACH/LANGE, Berlin, Germany). Generally, analyses of all the studied samples were accomplished following the recommendations in the APHA Standard Methods for the Examination of Water and Wastewater [23]. The general characteristics of the PSWW are presented in Table 1, in terms of minimum concentration values (Min), maximum values (Max), arithmetic mean (AM) as well as standard deviation (SD). From Table 2, it can be observed that the poultry slaughterhouse production processes generate relatively high polluted wastewater. 
Table 2. General characteristics of raw wastewater (number of samples $=12$ ).

\begin{tabular}{|c|c|c|c|c|c|c|c|}
\hline Parameter & Min & $\operatorname{Max}$ & Median & AM & SD & $\begin{array}{c}\text { Literature } \\
\text { (Min-Max) [24] }\end{array}$ & Unit \\
\hline $\mathrm{pH}$ & 7.2 & 7.4 & 7.4 & 7.3 & 0.094 & $7.3 \pm 0.42-8.6 \pm 0.42$ & \\
\hline Turbidity & 68.7 & 215 & 86 & 123.2 & 65.272 & 237-997 & FAU \\
\hline Color & 552 & 3490 & 2224 & 2089 & 1203.245 & NR & degree \\
\hline TSS & 116 & 569 & 224 & 303 & 193.189 & $313-8200$ & $\mathrm{mg} / \mathrm{L}$ \\
\hline Free chlorine & 0.04 & 0.09 & 0.08 & 0.07 & 0.022 & NR & $\mathrm{mg} / \mathrm{L}$ \\
\hline Total chlorine & 0.05 & 0.12 & 0.07 & 0.08 & 0.029 & NR & $\mathrm{mg} / \mathrm{L}$ \\
\hline Nitrite & 0.046 & 0.086 & 0.064 & 0.065 & 0.016 & NR & $\mathrm{mg} / \mathrm{L}$ \\
\hline Nitrate & 18.3 & 30.3 & 22 & 23.5 & 5.018 & $162.6-563.8$ & $\mathrm{mg} / \mathrm{L}$ \\
\hline Phosphates & 5.16 & 6.02 & 5.79 & 5.66 & 0.364 & $8-27$ & $\mathrm{mg} / \mathrm{L}$ \\
\hline Ammonium & 1.12 & 1.73 & 1.22 & 1.36 & 0.267 & NR & $\mathrm{mg} / \mathrm{L}$ \\
\hline Iron total & 1.22 & 1.44 & 1.33 & 1.33 & 0.090 & NR & $\mathrm{mg} / \mathrm{L}$ \\
\hline Aluminum & 0.11 & 0.89 & 0.64 & 0.55 & 0.325 & NR & $\mathrm{mg} / \mathrm{L}$ \\
\hline COD & 356 & 1409 & 1224 & 996 & 459.040 & $2133-12,490$ & $\mathrm{mg} / \mathrm{L}$ \\
\hline BOD & 77 & 570 & 464 & 370 & 211.884 & $925-5000$ & $\mathrm{mg} / \mathrm{L}$ \\
\hline
\end{tabular}

FAU = Formazin Attenuation Units, NR = not reported.

\subsection{Statistical Analysis}

The treatment efficiencies of the two main systems investigated in this study were calculated in terms of percentage based on the influent and effluent concentrations of the parameters of interest. Specifically, the computations of the treatment efficiencies was achieved by subtracting the concentration of the tested parameter after treatment from the one before treatment divided by the concentration before treatment then multiplied by 100 to convert the result into percentage as summarized in Equation (3).

$$
T_{e}(\%)=\left(\frac{C_{b}-C_{a}}{C_{b}}\right) \times 100
$$

where $T_{e}$ is treatment efficiency, $C_{b}$ concentration of a tested parameter before treatment, and $C_{a}$ is a concentration of a parameter after treatment.

Moreover, the influence of the electrolysis phase on the general efficiency of the treatment was calculated by the use of the cross-multiplication approach. Where final efficiency from the entire system is proportional to $100 \%$ while that of electrolysis is proportional to unknown. From the mathematical derivations, the contribution of the electrolysis phase on the general treatment efficiency for each parameter can be computed from Equation (4).

$$
C_{\text {ele }}(\%)=\frac{T_{\text {ele }} \times 100}{T_{e f}}
$$

where $C_{e l e}$ is the percentage contribution of the electrolysis phase, $T_{\text {ele }}$ is treatment efficiency from the electrolysis outlet and $T_{e f}$ treatment efficiency for the entire system.

Box and whisker plots were also used analyze data distribution among the selected parameters. The plots display the distribution of numerical data and skewness through data quartiles (percentiles) and averages.

\section{Results and Discussion}

The analysis of the water samples was successfully executed. In the raw wastewater samples, the average COD concentration was $996 \mathrm{mg} / \mathrm{L}$, while that of BOD was $370 \mathrm{mg} / \mathrm{L}$. The COD concentration in the raw wastewater is greater than $150 \mathrm{mg} / \mathrm{L}$ as recommended by 
the Jordanian standards for discharge to streams, wadis, and water storage areas. The BOD concentration is greater than $60 \mathrm{mg} / \mathrm{L}$ as also recommended by the Jordanian standards for discharge to streams, wadis, and water storage areas [25]. In the literature, average BOD concentrations of $875 \mathrm{mg} / \mathrm{L}$ and COD of $1301 \mathrm{mg} / \mathrm{L}$ from poultry slaughterhouse wastewater were recorded in conducted by Aziz, et al. [26]. The general phenomenon indicates that the poultry slaughterhouse wastewater is highly polluted requiring treatment prior to either discharge or any sort of reuse.

From Figure 3, it can be observed that the median line closer to the upper quartile with an indication that the distribution of COD data before treatment is considered to be "negatively skewed". This means the data constitute a higher frequency of more low concentration values than the high concentration values, the COD data distribution contained more values from $800 \mathrm{mg} / \mathrm{L}$ to approximately $1400 \mathrm{mg} / \mathrm{L}$. The median line from the COD values after the electrolysis treatment (AET) is observed to be closer to the lower quartile meaning that the water quality data constitute a higher frequency of more high concentration values than the low concentration values ("positively skewed"). The data distribution contained more data from above $10 \mathrm{mg} / \mathrm{L}$ to slightly above $20 \mathrm{mg} / \mathrm{L}$. Similarly, the median line from the COD values after the combined treatment (ACT) can be seen to be closer to the lower quartile meaning that the water quality data constitute a higher frequency of more high concentration values than the low concentration values ("positively skewed"). The data distribution contained more data from above $5 \mathrm{mg} / \mathrm{L}$ to slightly above $5 \mathrm{mg} / \mathrm{L}$.

From Figure 3, the median is observed to be closer to the lower quartile meaning that the TSS data before treatment constituted a higher frequency of more high concentration values than the low concentration values ("positively skewed"). The TSS data distribution contained more values from slightly above $200 \mathrm{mg} / \mathrm{L}$ to approximately $400 \mathrm{mg} / \mathrm{L}$. While, the median line from the TSS values after the electrolysis treatment (AET) is observed to be closer to the middle, indicating that the water quality data distribution is symmetric or normal. With the fact that an average concertation of $0 \mathrm{mg} / \mathrm{L}$ was achieved in the final effluent, the TSS boxplot becomes empty.

From Figure 3, the median is observed to be closer to the lower quartile meaning that the turbidity data before treatment constitute a higher frequency of more high concentration values than the low concentration values ("positively skewed"). The turbidity data distribution contained more values from slightly below 100 FAU to approximately 150 FAU. While, the median line from the turbidity values after the electrolysis treatment (AET) is observed to be closer to the middle, indicating that the water quality data distribution is symmetric or normal. A, with the fact that an average concertation of 0 FAU was achieved in the final effluent, the turbidity boxplot becomes empty.

Water samples were collected after the electrolysis phase to investigate the performance of the pre-treatment system at the scale before subjecting the wastewater to the membrane filtration and UV unit. The lab-scale electrolysis phase was able to significantly reduce pollution levels in the wastewater as observed in Table 3. For instance, the average turbidity in the raw wastewater was $123.2 \mathrm{mg} / \mathrm{L}$, while from the electrolysis effluent the turbidity concentration was $1.09 \mathrm{mg} / \mathrm{L}$. Color reduced from 2089 degrees to 57 degrees. TSS from $303 \mathrm{mg} / \mathrm{L}$ to $8.33 \mathrm{mg} / \mathrm{L}$, COD from $996 \mathrm{mg} / \mathrm{L}$ to $33.0 \mathrm{mg} / \mathrm{L}$ and BOD from $370 \mathrm{mg} / \mathrm{L}$ to $26.88 \mathrm{mg} / \mathrm{L}$. Phosphates from $5.66 \mathrm{mg} / \mathrm{L}$ to $0.39 \mathrm{mg} / \mathrm{L}$, total iron from $1.33 \mathrm{mg} / \mathrm{L}$ to $0.29 \mathrm{mg} / \mathrm{L}$. However, the electrolysis phase was not that much effective for some parameters such as nitrite and ammonium. Interestingly, the average concentration of aluminium was a little higher than that of the raw wastewater, which can be linked to the dissolution issues of the electrode and the operating scale of the system. 

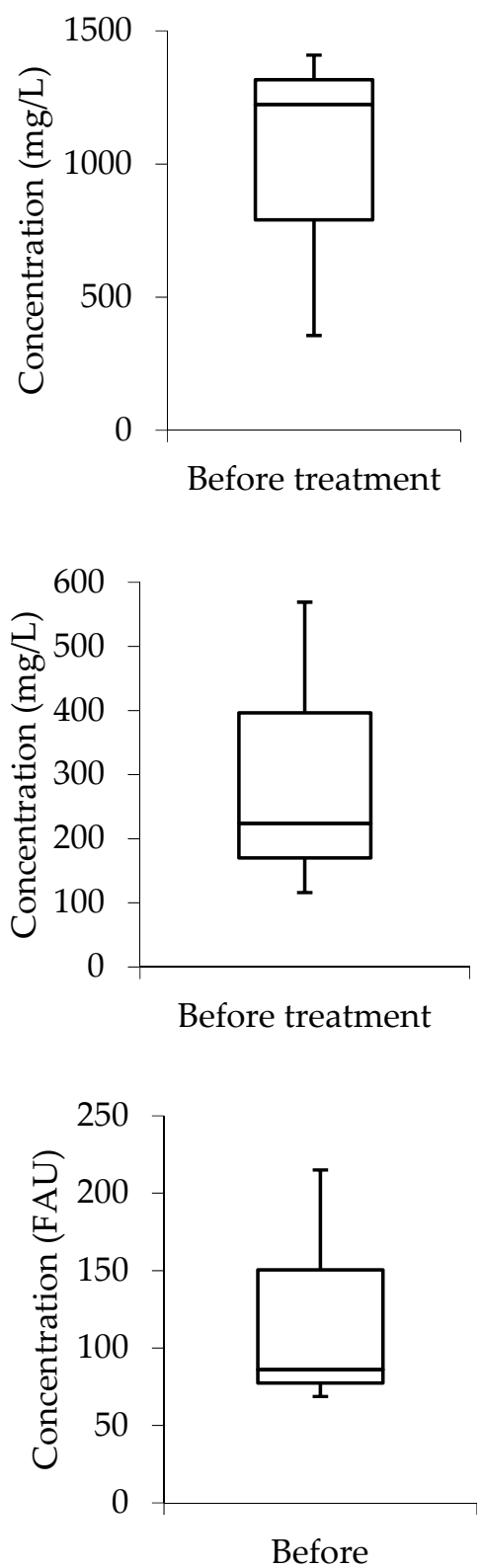

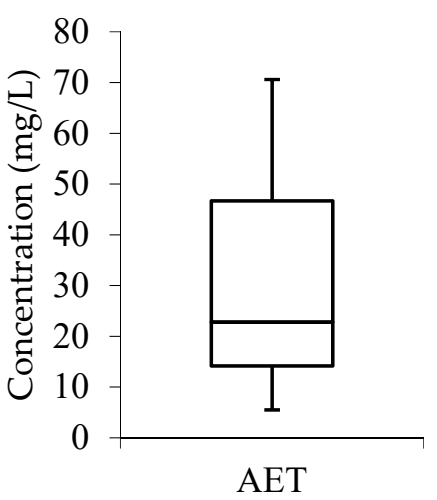

(a)

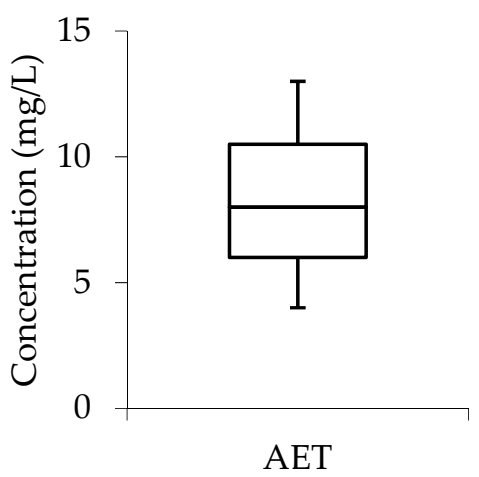

(b)

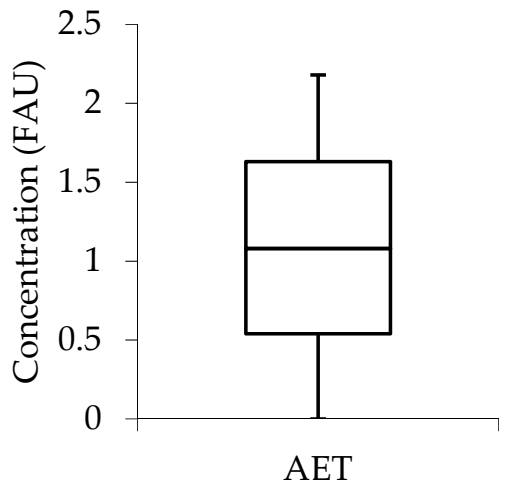

(c)
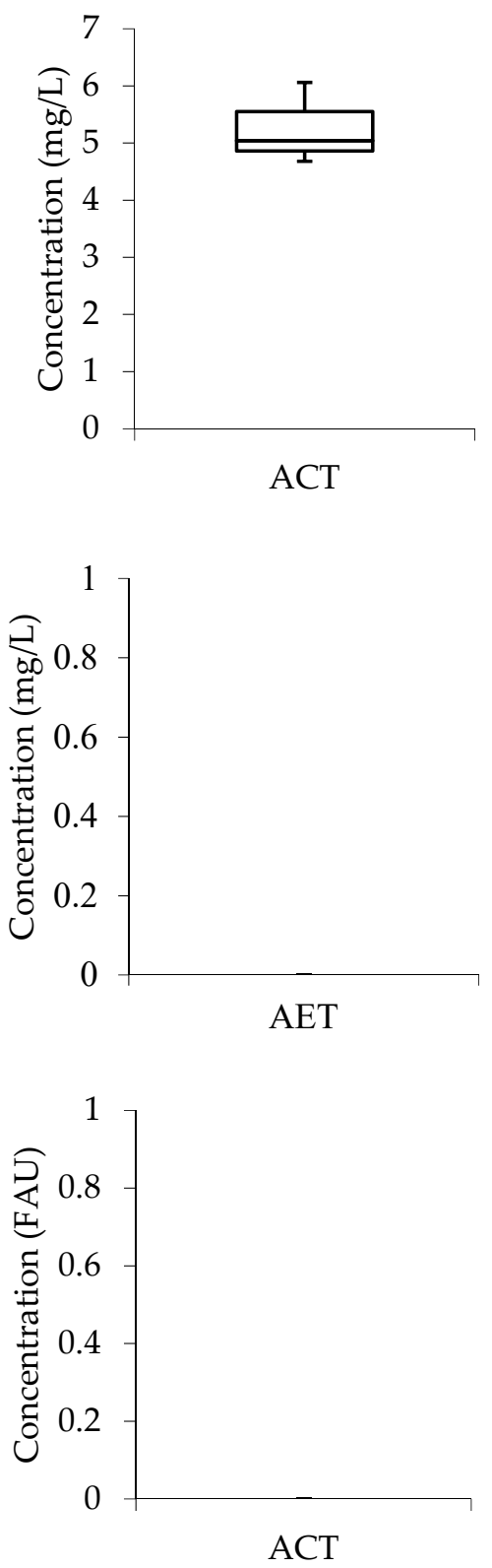

Figure 3. Data distribution (a) COD in raw wastewater, after electrolysis treatment (AET), and after combined treatment (ACT) (b) TSS (c) Turbidity.

From Table 4 , it can be observed that $88.8 \%$ removal efficiency was achieved from TSS after the electrolysis phase, which is also equivalent to $88.8 \%$ contribution in the final effluent. From free and total chlorine, the removal efficiency of 25 and $57 \%$, respectively was achieved. Which is equivalent to $50 \%$ removal contribution by the pre-treatment units for free chlorine and $100 \%$ for total chlorine. Moreover, removal efficiency of $30 \%$ was achieved from nitrites after the electrolysis phase which is also equivalent to a $33.5 \%$ contribution within the entire treatment process. From nitrates, 93.9\% removal efficiency was achieved from electrolysis effluent, equivalent to $98.2 \%$ removal contribution. 
Table 3. Analysis results for the studied physicochemical parameters.

\begin{tabular}{cccccc}
\hline Parameter & Min & Max & Median & AM & SD \\
\hline pH & 7.2 & 7.7 & 7.3 & 7.4 & 0.216 \\
Turbidity & 0 & 2.18 & 1.08 & 1.09 & 0.890 \\
Color & 33 & 90 & 49 & 57 & 24.005 \\
TSS & 4 & 13 & 8 & 8.33 & 3.682 \\
Free chlorine & 0.01 & 0.06 & 0.03 & 0.033 & 0.021 \\
Total chlorine & 0.02 & 0.04 & 0.03 & 0.03 & 0.008 \\
Nitrite & 0.04 & 0.08 & 0.06 & 0.06 & 0.016 \\
Nitrate & 0.8 & 5.6 & 1.1 & 2.5 & 2.195 \\
Phosphates & 0.02 & 1.08 & 0.06 & 0.39 & 0.491 \\
Ammonium & 0.12 & 1.59 & 1.03 & 0.91 & 0.606 \\
Total iron & 0.22 & 0.34 & 0.31 & 0.29 & 0.051 \\
Aluminum & 0.26 & 1.6 & 0.65 & 0.84 & 0.563 \\
COD & 5.5 & 70.6 & 22.8 & 33.0 & 27.532 \\
BOD & 3.96 & 72 & 4.68 & 26.88 & 31.906 \\
\hline
\end{tabular}

Moreover, the pre-treatment units were able to remove $79 \%$ and $70.7 \%$ of phosphates and ammonia, respectively from the wastewater. The removal efficiencies are equivalent to $79.3 \%$ and $92.5 \%$ removal contribution in the final effluent.

In general, the BOD, COD, nitrate, and TSS decreased significantly after the electrolysis phase. This is an indication that the pre-treatment units were capable of removing the majority of the pollutants in the wastewater. The combination of units to the electrolysis process had a 100\% contribution on the removal efficiency of the total chlorine in which other units such as ultra-cleaning, reverse osmosis, and the ultraviolet lamp had $0 \%$ removal influence on the total chlorine. A 30\% nitrite removal efficiency was achieved by the electrolysis unit which is equivalent to $33.5 \%$ removal contribution within the entire treatment plant, marking the lowest removal contribution. However, the general removal efficiency of the entire system for the nitrite showed some impressive results with a removal efficiency of $89.5 \%$. This means from $30 \%$ of the electrolysis phase, the remaining $59.5 \%$, equivalent to $66.5 \%$ removal contribution was accomplished by the other treatment units after the electrolysis.

From Table 4, it can be observed that the treatment efficiency of the integrated wastewater treatment system generally reached a removal efficiency of $100 \%$ for some parameters such as TSS. More than $80 \%$ removal efficiency was also achieved for most of the samples including nitrite nitrogen $(89.5 \%)$, nitrate-nitrogen with (95.6\%), ammonium $(99.2 \%)$ as well as BOD5 $(99.6 \%)$. Some of the challenge can be observed from the free chlorine and total chlorine with $50 \%$ and $57 \%$ removal efficiency respectively.

The combination of electrolysis and ultrafiltration provides a high and constant removal efficiency of TSS in the integrated treatment system due to their compatibility. While the electrolysis process works on removing the TSS from the wastewater, the ultrafiltration removes low solids slurry resulting from the electrolysis. Therefore, with their combination, the efficiency of the treatment system improves significantly.

Table 4. The removal efficiencies for chemical contaminants.

\begin{tabular}{cccc}
\hline Parameter & AET (\%) & ACT $\mathbf{( \% )}$ & Contribution of Electrolysis, $C_{\text {ele }}(\mathbf{\%})$ \\
\hline TSS & 88.8 & 100 & 88.8 \\
Free chlorine & 25 & 50 & 50.0 \\
Total chlorine & 57 & 57 & 100.0 \\
Nitrite & 30 & 89.5 & 33.5 \\
Nitrate & 93.9 & 95.6 & 98.2 \\
Phosphates & 79 & 99.6 & 79.3 \\
Ammonium & 70.7 & 76.4 & 92.5 \\
COD & 87.6 & 99.2 & 88.3 \\
BOD & 94.9 & 99.6 & 95.3 \\
\hline
\end{tabular}


Figure 4 shows removal efficiencies above $80 \%$ for some parameters from the electrolysis phase effluent and more parameters after the complete treatment system. The total chlorine concentration of $0.07 \mathrm{~mL} / \mathrm{dm}^{3}$ before purification was reduced to $0.03 \mathrm{~mL} / \mathrm{dm}^{3}$ after the electrolysis stage and then remained the same after the complete combined system. From Figure 5, it can also be observed that after the electrolysis phase the other treatment units did not influence the removal of the total chlorine as the removal efficiency remained the same. However, the complex relationship between the total and free chlorine may have influenced the phenomenon as total chlorine is defined as a sum of free and combined chlorine. In general, Figure 5 shows a high influence of the electrolysis phase on the purification ability of the integrated treatment system.

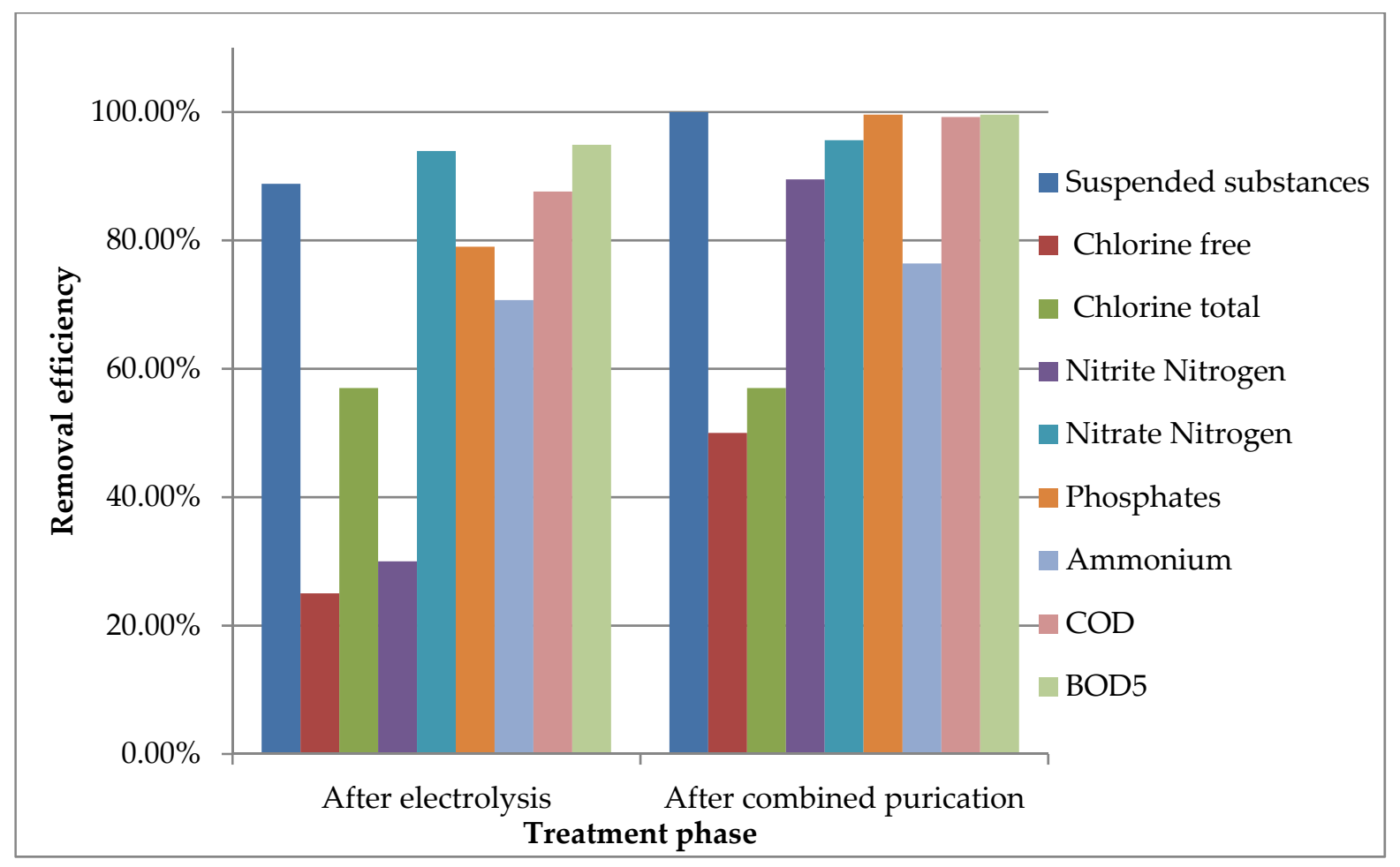

Figure 4. Treatment efficiencies for physio-chemical parameters.

Figure 5 shows the ranking in terms of the percent contribution of the electrolysis unit on the removal of the studied parameters in the within the integrated treatment system. It can be observed that the electrolysis unit had a removal influence of more than $50 \%$ for most of the studied physicochemical parameters. The highest removal contribution was observed for total chlorine while having a low influence on the removal of the nitrite.

This study reveals that the combination of an averaging tank, feather catcher, fat catcher, coarse mechanical filter, and electrolysis treatment units can be useful enough for poultry wastewater purification before discharge or recycled for non-portable uses. The combination also shows a promising potential towards improving the quality of the final effluent under the addition of other treatment units such as ultra-filtration, reverse osmosis, and an ultraviolet lamp. The key focus of any wastewater purification process is to remove different forms of pollutants such as solids, organic carbon, nutrients, inorganic salts, and metals as well pathogens leading to the deterioration of the water quality [27]. Moreover, effective wastewater collection and treatment plays a great role in protecting both the environment and public health [28], especially for a chlorine-free treatment system as numerous inorganic and organic micropollutants can undergo reactions with chlorine [29]. 


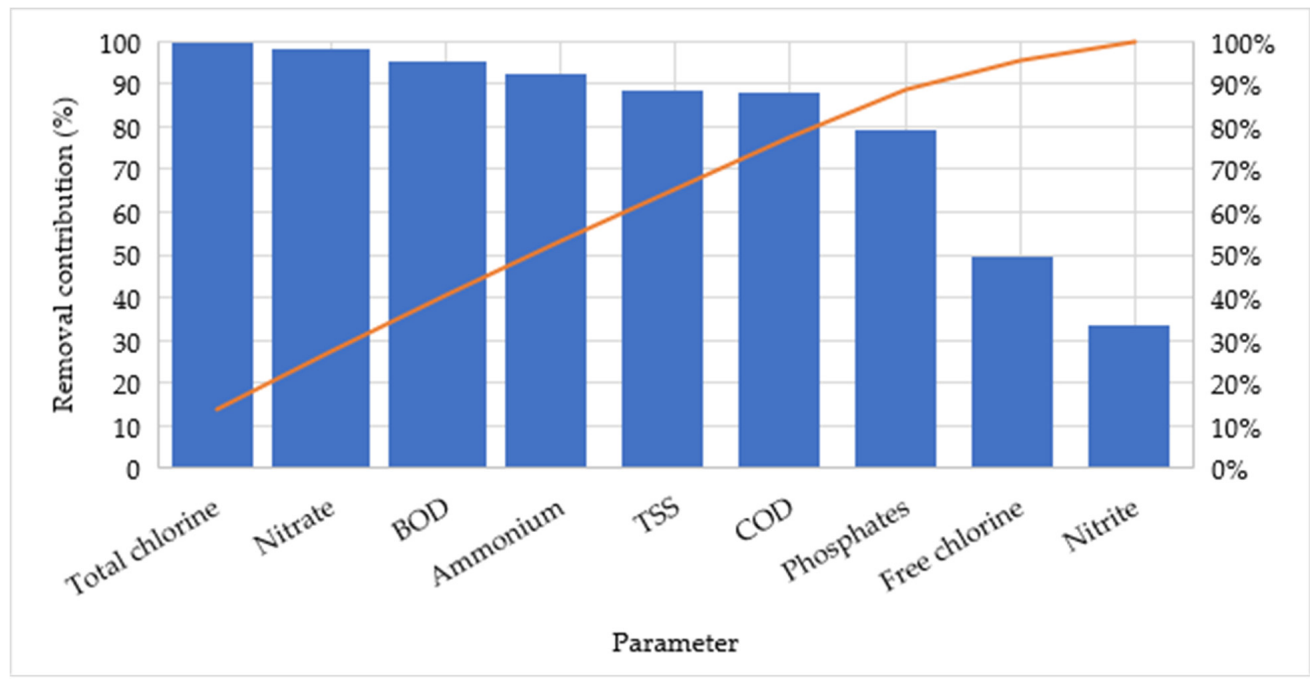

Figure 5. Ranking of electrolysis influence on the studied parameters.

\section{Conclusions}

The performance influence of the electrolysis unit in a lab-scale integrated wastewater treatment plant connected in series with other treatment units such as ultra-cleaning, reverse osmosis, and the ultraviolet lamp has been investigated. From the results, it was observed that the pre-treatment phase with electrolysis had a removal contribution ranging from $33.5 \%$ to $100 \%$. The highest removal contribution was observed from total chlorine $(100 \%)$, nitrate $(98.2 \%)$, as well as BOD $(95.3 \%)$. While the lowest contribution was observed from the nitrite removal, with $33.5 \%$. In general, the electrolysis process allowed the wastewater purification process to be accomplished electrochemically through oxidizing or reducing organic contaminants converting them into non-hazardous inorganic materials or substances. This study revealed further that the integration of electrolysis technology in a wastewater treatment system has a significant potential towards developing an effective wastewater treatment plant.

Author Contributions: Conceptualization, K.M.; methodology, K.M. and T.M.; software, A.K., Y.N. and T.M.; validation, Y.N., A.Z., M.K. and T.U.; formal analysis, T.M. and A.K.; investigation, resources, and data curation, K.M, Y.N., A.Z., M.K., T.U. and T.M.; writing-original draft preparation, T.M.; writing-review and editing, K.M., A.K. and T.M.; visualization, K.M., A.K. and T.M.; supervision, project administration, and funding acquisition, K.M. All authors have read and agreed to the published version of the manuscript.

Funding: This research was funded by the Ministry of Education and Science, the Republic of Kazakhstan to support "Reducing the technogenic impact on water resources with using water recycling technology", $\mathrm{N}^{\circ} \mathrm{BR} 05236844$ /215 for the years 2018-2020.

Institutional Review Board Statement: Not applicable.

Informed Consent Statement: Not applicable.

Data Availability Statement: Not applicable.

Conflicts of Interest: The authors declare no conflict of interest. The funders had no role in the design of the study; in the collection, analyses, or interpretation of data; in the writing of the manuscript, or in the decision to publish the results.

\section{References}

1. Fletcher, D.L. Poultry Meat: Processing. In Encyclopedia of Animal Science; CRC Press: Boca Raton, FL, USA, 2004; pp. 740-743. ISBN 9781420042177.

2. Rajakumar, R.; Meenambal, T.; Banu, J.R.; Yeom, I.T. Treatment of poultry slaughterhouse wastewater in upflow anaerobic filter under low upflow velocity. Int. J. Environ. Sci. Technol. 2011, 8, 149-158. [CrossRef] 
3. Meiramkulova, K.; Temirbekova, A.; Saspugayeva, G.; Kydyrbekova, A.; Devrishov, D.; Tulegenova, Z.; Aubakirova, K.; Kovalchuk, N.; Meirbekov, A.; Mkilima, T. Performance of a Combined Treatment Approach on the Elimination of Microbes from Poultry Slaughterhouse Wastewater. Sustainability 2021, 13, 3467. [CrossRef]

4. Meiramkulova, K.; Orynbekov, D.; Saspugayeva, G.; Aubakirova, K.; Arystanova, S.; Kydyrbekova, A.; Tashenov, E.; Nurlan, K.; Mkilima, T. The Effect of Mixing Ratios on the Performance of an Integrated Poultry Slaughterhouse Wastewater Treatment Plant for a Recyclable High-Quality Effluent. Sustainability 2020, 12, 6097. [CrossRef]

5. Castro, R.D.P.V.D.; Mello, V.M.D.; Alexandre, V.M.F.; Cammarota, M.C. Pré-tratamento físico-químico e enzimático para efluente de abatedouro. Eng. Sanit. Ambient. 2019, 24, 975-981. [CrossRef]

6. Lu, J.; Li, W.; Du, X.; Ewert, D.L.; West, M.B.; Stewart, C.; Floyd, R.A.; Kopke, R.D. Antioxidants Reduce Cellular and Functional Changes Induced by Intense Noise in the Inner Ear and Cochlear Nucleus. J. Assoc. Res. Otolaryngol. 2014, 15, 353-372. [CrossRef]

7. Yusuf, Z.; Abdul Wahab, N.; Sudin, S. Soft computing techniques in modelling of membrane filtration system: A review. Desalin. WATER Treat. 2019, 161, 144-155. [CrossRef]

8. Maddah, H.A.; Alzhrani, A.S.; Bassyouni, M.; Abdel-Aziz, M.H.; Zoromba, M.; Almalki, A.M. Evaluation of various membrane filtration modules for the treatment of seawater. Appl. Water Sci. 2018, 8, 150. [CrossRef]

9. Bu, F.; Gao, B.; Yue, Q.; Liu, C.; Wang, W.; Shen, X. The Combination of Coagulation and Adsorption for Controlling UltraFiltration Membrane Fouling in Water Treatment. Water 2019, 11, 90. [CrossRef]

10. Lakatos, G. Biological Wastewater Treatment. In Principles of Membrane Bioreactors for Wastewater Treatment; CRC Press: Boca Raton, FL, USA, 2015; pp. 32-91. ISBN 9781536135800.

11. Muddemann, T.; Haupt, D.; Sievers, M.; Kunz, U. Electrochemical Reactors for Wastewater Treatment. ChemBioEng Rev. 2019, 6, 142-156. [CrossRef]

12. Lin, S.H.; Shyu, C.T.; Sun, M.C. Saline wastewater treatment by electrochemical method. Water Res. 1998, 32, 1059-1066. [CrossRef]

13. Meiramkulova, K.; Jakupova, Z.; Orynbekov, D.; Tashenov, E.; Kydyrbekova, A.; Mkilima, T.; Inglezakis, V.J. Evaluation of Electrochemical Methods for Poultry Slaughterhouse Wastewater Treatment. Sustainability 2020, 12, 5110. [CrossRef]

14. de Sousa, D.D.P.; Pinto, C.F.; Tonhela, M.A.; Granato, A.C.; Motheo, A.d.J.; Lima, A.d.F.; Ferreira, D.C.; Fernandes, D.M.; Fornazari, A.L.d.T.; Malpass, G.R.P. Treatment of real dairy wastewater by electrolysis and photo-assisted electrolysis in presence of chlorides. Water Sci. Technol. 2019, 80, 961-969. [CrossRef]

15. Ferrández-Gómez, B.; Ruiz-Rosas, R.; Beaumont, S.; Cazorla-Amorós, D.; Morallón, E. Electrochemical regeneration of spent activated carbon from drinking water treatment plant at different scale reactors. Chemosphere 2021, 264, 128399. [CrossRef]

16. Mostafa, E.; Baltruschat, H.; Garcia-Segura, S. Unraveling the role of electrolytes during electrochemical oxidation by differential electrochemical mass spectrometry. Electrochim. Acta 2021, 387, 138521. [CrossRef]

17. Kobya, M.; Senturk, E.; Bayramoglu, M. Treatment of poultry slaughterhouse wastewaters by electrocoagulation. J. Hazard. Mater. 2006, 133, 172-176. [CrossRef] [PubMed]

18. Chen, X.; Chen, G.; Yue, P.L. Novel Electrode System for Electroflotation of Wastewater. Environ. Sci. Technol. 2002, 36, 778-783. [CrossRef] [PubMed]

19. Meiramkulova, K.; Devrishov, D.; Zhumagulov, M.; Arystanova, S.; Karagoishin, Z.; Marzanova, S.; Kydyrbekova, A.; Mkilima, T.; $\mathrm{Li}$, J. Performance of an Integrated Membrane Process with Electrochemical Pre-Treatment on Poultry Slaughterhouse Wastewater Purification. Membranes 2020, 10, 256. [CrossRef]

20. Palmer, M.; States, U.; Protection, E.; Lakes, G.; Program, N. Standard Operating Procedure for GLNPO Total Alkalinity Titration. Environ. Prot. 1992, 3, 5-10.

21. Walter, W.G. Standard Methods for the Examination of Water and Wastewater (11th ed.). Am. J. Public Health Nations Health 1961, 51, 940. [CrossRef]

22. Zhu, Y.; Song, Y.; Yu, H.; Liu, R.; Liu, L.; Lv, C. Characterization of dissolved organic matter in Dongjianghu Lake by UV-visible absorption spectroscopy with multivariate analysis. Environ. Monit. Assess. 2017, 189, 443. [CrossRef]

23. Jenkins, S.H. Standard Methods for the Examination of Water and Wastewater. Water Res. 1982, 16, 1495-1496. [CrossRef]

24. Fatima, F.; Du, H.; Kommalapati, R.R. Treatment of Poultry Slaughterhouse Wastewater with Membrane Technologies: A Review. Water 2021, 13, 1905. [CrossRef]

25. World Health Organization. A Compendium of Standards for Wastewater Reuse in the Eastern Mediterranean Region; WHOEM/CEH/142/E; World Health Organization: Geneva, Switzerland, 2006; p. 19.

26. Aziz, H.; Puat, N.; Alazaiza, M.; Hung, Y.-T. Poultry Slaughterhouse Wastewater Treatment Using Submerged Fibers in an Attached Growth Sequential Batch Reactor. Int. J. Environ. Res. Public Health 2018, 15, 1734. [CrossRef] [PubMed]

27. Salgot, M.; Folch, M. Wastewater treatment and water reuse. Curr. Opin. Environ. Sci. Health 2018, 2, 64-74. [CrossRef]

28. Aghalari, Z.; Dahms, H.-U.; Sillanpää, M.; Sosa-Hernandez, J.E.; Parra-Saldívar, R. Effectiveness of wastewater treatment systems in removing microbial agents: A systematic review. Glob. Health 2020, 16, 13. [CrossRef] [PubMed]

29. Deborde, M.; von Gunten, U. Reactions of chlorine with inorganic and organic compounds during water treatment-Kinetics and mechanisms: A critical review. Water Res. 2008, 42, 13-51. [CrossRef] 